\title{
DETECTION OF QUINOLINE USING AMMONIA PLASMA-FUNCTIONALISED MULTI-WALLED CARBON NANOTUBES AND APPLICATION TO REAL SAMPLES
}

\author{
ZULAIHA ABDUL RAHIM*; NOR AZAH YUSOF**; AZIZUL ISHA;; MUHAMMAD ANIQ SHAZNI \\ MOHAMMAD HANIFF";; FARUQ MOHAMMAD¥\#\#; MOHD ISMAHADI SYONO¥\# \\ and NURULHAIDAH DAUD ${ }^{\ddagger}$
}

\begin{abstract}
Study on the growth of multi-walled carbon nanotubes (MWCNT) using plasma-enhanced chemical vapour deposition (PECVD) techniques has been carried out in this work. MWCNT screen-printed electrode (SPCE) based on silicon substrate was fabricated for quinoline detection using photolithography methods. The MWCNT working electrodes were modified under ammonia $\left(\mathrm{NH}_{3}\right)$ plasma to enhance the surface sensitivity to detect quinoline. The electrocatalytic activity of modified electrode towards oxidation of quinoline was evaluated using cyclic voltammetry (CV) and linear sweep voltammetry (LSV). Under experimental conditions, peak currents increased with an increase in the concentration of quinoline (dynamic range = 2.0 to $25.0 \mu \mathrm{M})$ and displayed good linearity $\left(R^{2}=0.9958\right)$. The limit of detection (LOD) was calculated to be $0.164 \mu \mathrm{M}$. The modified electrode was then applied to real samples sourced from both healthy and Ganoderma boninense infected oil palm roots crude extracts. A linear plot was obtained with a good linearity $\left(R^{2}=0.9879\right)$, indicating good sensing results.
\end{abstract}

Keywords: electrochemical sensor, Ganoderma boninense, multi-walled carbon nanotubes, quinoline, screen-printed carbon electrode.

Received: 22 March 2019; Accepted: 11 November 2019; Published online: 8 October 2020.

\section{INTRODUCTION}

Ganoderma is a group of wood degrading fungi with hard fruiting bodies. Various species of

* Institute of Advanced Technology,

Universiti Putra Malaysia, 43400 UPM Serdang,

Selangor, Malaysia.

E-mail: azahy@upm.edu.my

** Department of Chemistry, Faculty of Science, Universiti Putra Malaysia, 43400 UPM Serdang, Selangor, Malaysia.

‡ Natural Medicines and Product Research, Institute of Bioscience, Universiti Putra Malaysia, 43400 UPM Serdang, Selangor, Malaysia.

执 MIMOS Berhad, Jalan Inovasi 3 , Technology Park Malaysia, 57000 Kuala Lumpur, Malaysia.

执 Surfactant Research Chair, Department of Chemistry, College of Science, King Saud University,

P. O. Box 2455, 11451Riyadh, Saudi Arabia.
Ganoderma have been identified in previous studies (Hushiaran et al., 2013). Ganoderma sp. has been reported as the major cause of basal stem rot (BSR) and upper stem rot diseases which eventually lead to the death of oil palm. In 1985, Ho and Nawawi collected several hundred sporophores of Ganoderma from 5-40 years old oil palms infected with BSR in five oil palm estates in Peninsular Malaysia to identify the species of Ganoderma. They found that all the Ganoderma sporophores that they collected belonged to a single species, i.e. Ganoderma boninense. Recent findings showed that BSR disease as a single major devastating disease constraint to oil palm plantations in Malaysia and Indonesia (Azahar et al., 2014; Lisnawati et al., 2016). Despite the presence of various Ganoderma species, Ganoderma boninense has been reported as the main pathogen causing the BSR disease in oil palm (Khairuddin, 1990). 
Plants produce a variety of primary and secondary metabolites in response to various environmental factors. Secondary metabolites play important roles in plant protection which might involve deterrent or anti-feedant activity, toxicity or acting as precursors to physical defence systems. Numerous specialist herbivores and pathogens do not merely avoid the deterrent or toxic effects of secondary metabolites but actually utilise these compounds as either host recognition signals or nutrients or both (Bennet and Wallsgrove, 1994; Nusaibah et al., 2016).

Ganoderma boninense infection in oil palms surges the release of metabolites which can be used as indicators for early detection of infection in oil palms (Choon, 2011; Dutse et al., 2012; Fang and Ramasamy, 2015; Idris et al., 2006; Idris and Rafidah, 2008; Madihah et al., 2014; Mohd Su'ud et al., 2007; Nurnadiah et al., 2014; Wong et al., 2012). Nusaibah et al. (2016) has studied the accumulation of an alkaloid secondary metabolite such as quinoline in oil palm roots at early stages of Ganoderma boninense infection. Quinoline which is belong to alkaloids group of secondary metabolites is derived from tryptophan, an amino acid-based precursor (Akanbi et al., 2017). Development of rapid detection of the quinoline compound at the early stage is crucial to prevent the continuous devastating loss of stands in the oil palm plantations.

Electrochemical sensors have extensively been applied in many fields such as biomedical, environmental and agricultural with diverse industrial applications. High requests of electrochemical sensors in the world market are due to their compatibility, fast result and easy to handle (miniature in size, usually micro to nano range). In electrochemical biosensors, measurement of current produced is taken either from oxidation or reduction process. The current response is either due to the concentration of the electroactive species present or its rate of production or consumption. The resulting electrical signal is related to the recognition process by target analyte, and is proportional to the analyte concentration.

In this study, an electrochemical sensor using voltammetry approach was fabricated based on multi-walled carbon nanotubes (MWCNT) material as sensing part. Even though carbon nanotubes (CNT) display many outstanding properties but their surface inertness has restricted the application of CNT as the sensing area on the sensor. To overcome this limitation, modification on the surface of CNT has been one of the most vital aspects in carbon nanotube studies. Production of MWCNT/silicon (Si) screen-printed electrode (SPE) is necessary to provide plasma growth of the nanotubes and also plasma modification on the surface of the working electrodes. Compared to conventional chemical method, plasma method offer several advantages such as highly dense and uniform CNT films productions with an outstanding reproducibility and adhesion at relatively high deposition rate (Fu and $\mathrm{Yu}, 2014$ ).

Our previous work has reported the posttreatment effects of applying different plasma atmospheric conditions such as hydrogen $\left(\mathrm{H}_{2}\right)$, oxygen $\left(\mathrm{O}_{2}\right)$ and ammonia $\left(\mathrm{NH}_{3}\right)$ plasma on the electrochemical performances of the MWCNT (Abdul Rahim et al., 2018). Surface modification is a good way to improve the electrical conductivity of the MWCNT. Based on our findings, the $\mathrm{NH}_{3}$-treated MWCNT show the highest efficiency as compared to the other pre-treatments and control. This is due to the enhanced surface area of the composite, which improved adsorption and associated interaction with that of the analyte molecules at the electrodes.

In the present work, the electrochemical characterisation of the $\mathrm{NH}_{3} / \mathrm{MWCNT}$ electrodes for the detection of quinoline and the application to the real samples sourced from both healthy and Ganoderma boninense infected oil palm roots crude extracts were carried out to determine the performance of the modified electrode.

\section{MATERIALS AND METHODS}

\section{Preparation of Working Solution}

Quinoline stock solution (1 mol litre $\mathrm{e}^{-1}$ ) was prepared by diluting $8.9 \mathrm{~mol}^{\text {litre }} \mathrm{e}^{-1}$ standard solution of quinoline with deionised water. Working solution of quinoline was prepared just before use by diluting the stock solution in $0.1 \mathrm{~mol}^{\text {litre }} \mathrm{e}^{-1}$ phosphate buffer solution (PBS) supporting electrolyte.

\section{Preparation of MWCNT Electrodes}

Preparation of MWCNT electrodes followed our previously reported studies (Abdul Rahim et al., 2018). Titanium (Ti) conducting layer and cobalt (Co) catalyst film were deposited onto Si substrates with crystallographic orientations (100) [(Si (100)] by using magnetron sputtering at a base chamber pressure of $\sim 10^{-3}$ mbar and temperature of $42^{\circ} \mathrm{C}$ in $20 \mathrm{~s}$. MWCNT were then synthesised by using plasma-enhanced chemical vapour deposition (PECVD) in an Oxford Instruments Nanofab-700 system at ambient pressure. The catalyst films underwent annealing process to promote the formation of catalyst nanoparticles for CNT growth in vacuum at $700^{\circ} \mathrm{C}$ for $10 \mathrm{~min}$ in $\mathrm{NH}_{3} ; 99.99 \%$ pure at flow rate of 100 standard cubic centimeter per minute $(\mathrm{sccm})$, with an applied plasma power of $200 \mathrm{~W}$. The MWCNT growth was performed in the same furnace chamber with $50 \mathrm{sccm}$ of acetylene, $\mathrm{C}_{2} \mathrm{H}_{2}(99.99 \%$ pure) at a pressure of 1000 mTorr at $700^{\circ} \mathrm{C}$ for $10 \mathrm{~min}$. Both the pristine and 
plasma-modified MWCNT were characterised by using electrochemical technique, i.e. potentiostatic system of cyclic voltammetry (CV).

\section{Electrochemical Measurements}

Electrochemical measurement was carried out using Dropsens Potentiostat with the screenprinted $\mathrm{NH}_{3}-\mathrm{MWCNT} / \mathrm{Si}$ electrode. The working and counter electrode were made up of CNT whereas the reference electrode was made up of silver. During electrochemical detection, 0.1 M PBS ( $\mathrm{pH}$ 7.0) was used as the supporting electrolyte for the detection of quinoline. After $60 \mathrm{~s}$ deposition time at $-0.6 \mathrm{~V}$, the linear sweep anodic stripping voltammograms (LSASV) were recorded from -0.6 to $0.6 \mathrm{~V}$, and the oxidation peak current at $0.15 \mathrm{~V}$ was measured. The scan rate used was $100 \mathrm{mVs}^{-1}$.

\section{Electrochemical Response of Quinoline on $\mathrm{NH}_{3} /$ MWCNT Electrode}

Different modified Si electrodes were used to investigate the oxidation response of $20 \mu \mathrm{M}$ quinoline using LSASV. Figure 2 shows the voltammograms of bare and modified electrodes towards detection of quinoline in $0.1 \mathrm{M}$ PBS solution ( $\mathrm{pH} 7.0)$ under optimal conditions (scan rate $=100 \mathrm{mV} \mathrm{s}^{-1}$; potential range $=-0.6$ to $0.6 \mathrm{~V}$ ).

\section{Optimisation of the Working Conditions for Modified Electrode in Quinoline}

Various working conditions for the detection of quinoline were optimised. These conditions included influence of $\mathrm{pH}$ on the current response, effect of accumulation potential and time, effect of varying scan rates and quinoline concentration. Each experiment was performed in triplicate.

\section{Influence of $\mathrm{pH}$ on the Current Response}

Different $\mathrm{pH}$ values from 4 to 12 of PBS solution $\left(0.1 \mathrm{~mol}^{\text {litre }}{ }^{-1}\right)$ were analysed using scan rate of 100 $\mathrm{mVs}^{-1}$. Potential scanning was performed in -0.6 to $+0.6 \mathrm{~V}$ at scan rate $100 \mathrm{mVs}^{-1}$; accumulation potential $-0.6 \mathrm{~V}$ and accumulation time for $50 \mathrm{~s}$. The oxidation peak current was monitored with various $\mathrm{pH}$ values used in the experiment.

\section{Effect of Accumulation Potential}

Accumulation potential was varied towards positive direction from -1.0 to $+0.6 \mathrm{~V}$ and applied for electrochemical analysis of $\mathrm{NH}_{3} / \mathrm{MWCNT}$ using 0.1 M PBS as supporting electrolyte with accumulation time of $50 \mathrm{~s}$. The oxidation peak current was monitored with various accumulation potential used in the experiment.

\section{Effect of Accumulation Time}

Accumulation potential was varied from 30$120 \mathrm{~s}$ and used for the electrochemical analysis of $\mathrm{NH}_{3} / \mathrm{MWCNT}$ employing $0.1 \mathrm{M}$ PBS $(\mathrm{pH}=7)$ as supporting electrolyte with accumulation potential of $-0.6 \mathrm{~V}$. The oxidation peak current was monitored with various accumulation time used in the experiment.

\section{Effect of Varying Scan Rates}

A series of scan rate from 10 to $100 \mathrm{mVs}^{-1}$ were used for the electrochemical analysis of $\mathrm{NH}_{3}$ / MWCNT in 0.1 M PBS ( $\mathrm{pH} 7$ ) with accumulation potential of $-0.6 \mathrm{~V}$ used at $50 \mathrm{~s}$ accumulation time. The oxidation peak current was monitored with various scan rate used in the experiment.

\section{Effect of Varying Quinoline Concentration}

The $\mathrm{NH}_{3}$ / MWCNT was used to analyse different concentration of quinoline using LSASV technique. Potential scanning was performed in a positive direction at scan rate of $100 \mathrm{mVs}^{-1}$. The concentration of quinoline applied were $25 \mu \mathrm{M}$ down to $2 \mu \mathrm{M}$ diluted in PBS $(\mathrm{pH}=7)$ solution. Accumulation potential of $-0.6 \mathrm{~V}$ was used at $50 \mathrm{~s}$ accumulation time.

\section{Electrochemical Characterisation of Developed Electrode for Quinoline Detection}

The reproducibility study of the modified $\mathrm{NH}_{3} /$ MWCNT was carried out in the concentration of $10 \mu \mathrm{mol}$ litre $^{-1}$ quinoline standard solution. Reproducibility of the method was determined by analysing five different batches of similarly constructed modified SPE placed in quinoline solution and the average and standard deviation (SD) of the peak current were calculated. Stability of the $\mathrm{NH}_{3} / \mathrm{MWCNT}$ was studied by recording the peak current every day with the single $\mathrm{NH}_{3}$ / MWCNT.

\section{Analysis of Real Samples}

Healthy and artificially inoculated Ganoderma boninense infected oil palm roots were used as real samples in this study to investigate the potential of developed electrode.

\section{Inoculation of Ganoderma boninense Using Rubber Wood Block and Plant Cultivation}

The rubber wood block was prepared according to the method previously described (Idris et al., 2006). Cultures of Ganoderma boninense PER 71 were obtained from the stock collection of 
the Department of Plant Protection, Faculty of Agriculture, Universiti Putra Malaysia, Selangor, Malaysia. Rubber wood blocks of $6 \mathrm{~cm} \times 6 \mathrm{~cm} \times 6$ $\mathrm{cm}$ were purchased from Wah Heng Rubber Wood Factory Sdn Bhd, Semenyih, Selangor. Cut pieces of Ganoderma boninense measuring $1 \mathrm{~cm} \times 1 \mathrm{~cm}$ were inoculated into the rubber wood blocks and incubated in the dark for 30 days until the blocks were fully colonised.

Commercial DxP GH500 germinated seedlings (3 months old) from Sime Darby Seeds \& Agricultural Services Sdn Bhd, Banting, Selangor were used in this work. Five germinated seedlings were treated with $G$. boninense inoculated rubber wood blocks and another five germinated seedlings with non-inoculated rubber wood blocks were used as control. Treatment was performed for up to 30 days. Leaf samples were harvested at 30 days post-infection. Liquid nitrogen was used to quench each sample and ground into powder form before being stored at $-80^{\circ} \mathrm{C}$. Freeze-dry system (Scanvac Labogene) was employed to remove the water content in the samples.

\section{Extraction of Healthy and Ganoderma boninense Infected Oil Palm Roots and Sample Preparation}

The root powder of infected oil palm (150 $\mathrm{mg}$ ) was extracted via sonication in $250 \mathrm{ml}, 80 \%$ commercial-grade methanol $\left(30 \mathrm{~min}, 40^{\circ} \mathrm{C}\right.$ ). The supernatant was filtered by using filter paper (Whatman, $125 \mathrm{~mm}$ ) and then evaporated by using rotary evaporator. Healthy and Ganoderma boninense infected oil palm roots crude extract stock solutions (200 mg litre $\mathrm{m}^{-1}$ ) were prepared by dissolving 2 $\mathrm{mg}$ of healthy and Ganoderma boninense infected oil palm roots crude extract in $0.1 \mathrm{ml}$ methanol, followed by dilution in PBS solution ( $\mathrm{pH}$ 7.0) in $10 \mathrm{ml}$ volumetric flask. Different concentrations (10-100 mg litre $\left.{ }^{-1}\right)$ of healthy and G. boninese crude extract solutions were prepared by serial dilution of the stock solution ( $200 \mathrm{mg}$ litre $^{-1}$ ) of the respective extract.

\section{Application of Developed Electrode to Real Samples}

The characterisation of the developed electrode in real samples (healthy and Ganoderma boninense infected roots crude extracts) was conducted under the optimised conditions. The linear sweep voltammetry (LSV) measurement were performed for different concentrations of real samples. Reproducibility study was also performed in this work. Each real sample (healthy and Ganoderma boninense infected roots crude extracts) was determined in triplicates of LSV cycles and relative standard deviation (RSD) cum percentage recovery were evaluated.

\section{RESULTS AND DISCUSSION}

Figure 1 shows the schematic design of screen printed MWCNT electrode. Every single SPE was made up of reference electrode deposited with silver whereas counter and working electrodes were deposited with MWCNT.

In our previous work, we discussed the surface morphologies of as-grown MWCNT film before and after being exposed to $\mathrm{NH}_{3}$ plasma, by providing the field emission scanning electron microscope (FESEM) images. From the FESEM analysis, the surface defects of the plasma modified MWCNT were improved after exposing to $\mathrm{NH}_{3}$ plasma. The MWCNT surface changed from smooth to rough and the outer diameters of the modified MWCNT decreased.

Raman spectroscopy has been employed in our previous work to study the quality of MWCNT after treatment with $\mathrm{NH}_{3}$ plasma (Abdul Rahim et al., 2018). Three different peaks, i.e. $1360 \mathrm{~cm}^{-1}$, $1580 \mathrm{~cm}^{-1}$ and $2700 \mathrm{~cm}^{-1}$ which referred to the $\mathrm{D}$, $\mathrm{G}$ and $2 \mathrm{D}$ bands, respectively were observed. This observation confirmed the MWCNT formation. The existence of both $\mathrm{D}$ and $2 \mathrm{D}$ bands was due to the presence of defects or amorphous-phase carbon by the $\mathrm{NH}_{3}$ plasma treatment. The presence of $\mathrm{G}$ band indicates the $\mathrm{C}-\mathrm{C}$ stretching of the $\mathrm{sp} 2$ graphite or ordered-phase carbon. The ratio between $\mathrm{D}$ and $\mathrm{G}$ band intensity $(R=\mathrm{ID} / \mathrm{IG})$ which provides the information on the relative amounts of structural defects (degree of perfection) of the MWCNT was also carried out in our previous work. The value of $R$ ratio increased after MWCNT was treated with $\mathrm{NH}_{3}$ plasma. This can be indicated by the formation of electron deficient moieties at the MWCNT surface due to the $\mathrm{NH}_{3}$ plasma treatment.

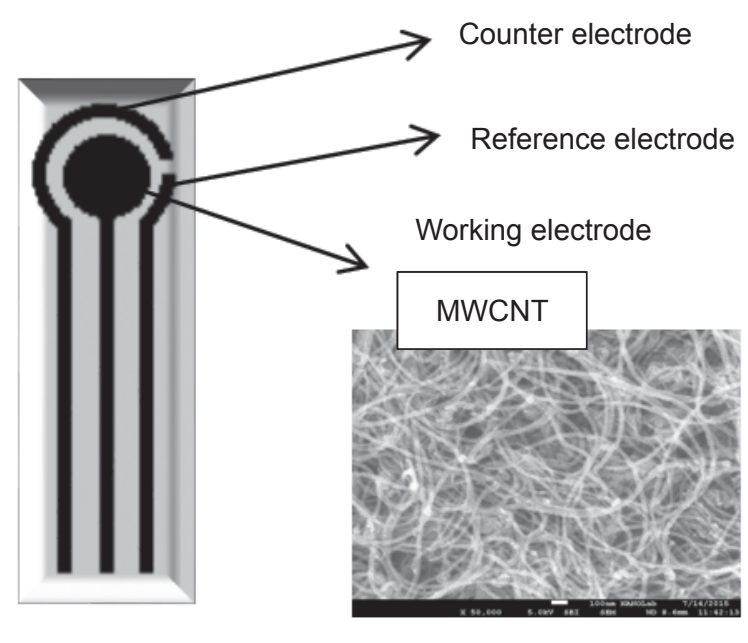

Figure 1. Schematic design of multi-walled carbon nanotubes (MWCNT)/silicon electrode. 


\section{Electrochemical Response of Quinoline on $\mathrm{NH}_{3} /$} MWCNT Electrode

Differently modified Si electrodes were used to investigate the oxidation response of $20 \mu \mathrm{M}$ quinoline LSASV. Figure 2 shows the voltammograms of bare and modified electrodes towards detection of quinoline in 0.1 M PBS solution ( $\mathrm{pH} 7.0$ ) under optimal conditions (scan rate $=100 \mathrm{mV} \mathrm{s}^{-1}$; potential range $=-0.6$ to $0.6 \mathrm{~V}$ ). There is no significant oxidation peak observed after $60 \mathrm{~s}$ accumulation time after single solution of 0.1 M PBS solution ( $\mathrm{pH}$ 7.0) was introduced to $\mathrm{NH}_{3} / \mathrm{MWCNT}$ electrode (Figure 2a). An oxidation peak was observed in the curve of bare MWCNT electrode at the peak current of $87 \mu \mathrm{A}$ with the potential of $+0.12 \mathrm{~V}$ after addition of $20 \mu \mathrm{M}$ quinoline into the $0.1 \mathrm{M}$ PBS solution ( $\mathrm{pH}$ 7.0) (Figure 2b). This indicates that the oxidation peak at $+0.12 \mathrm{~V}$ is due to the oxidation of quinoline. The $\mathrm{NH}_{3} / \mathrm{MWCNT}$ electrode was then used to observe the oxidation response of quinoline in 0.1 M PBS solution ( $\mathrm{pH} 7.0$ ). As shown in Figure $2 c$, a sharp and well-defined oxidation peak at $+0.12 \mathrm{~V}$ with the current response of $252 \mu \mathrm{A}$ was observed. The $\mathrm{NH}_{3} / \mathrm{MWCNT}$ electrode showed an increase in the oxidation response signal of quinoline when compared to bare MWCNT electrode (Figure 2).

Comparison of $\mathrm{NH}_{3} / \mathrm{MWCNT}$ electrode with other plasma treatment electrodes such as $\mathrm{H}_{2} /$ MWCNT and $\mathrm{O}_{2} /$ MWCNT has been made in our previous work (Abdul-Rahim et al., 2018). In our previous finding, $\mathrm{NH}_{3} / \mathrm{MWCNT}$ electrode showed the highest redox peak currents followed by $\mathrm{H}_{2}$ / MWCNT and $\mathrm{O}_{2} /$ MWCNT. Functionalisation of $\mathrm{NH}_{3}$ on MWCNT surface had greatly enhanced the surface performance by enlarging the surface area and this led to high accumulation efficiency of quinoline oxidation. Furthermore, improvement of the current signals is correlated to the increment of the diffusion rate of $\mathrm{K}_{3} \mathrm{Fe}(\mathrm{CN})_{6}$ and larger effective surface area that improved the sensitivity of the nanotubes' surfaces (Taurino et al., 2012). Hence, the sensitivity of the electrode surface has been improved for detection of quinoline. The proposed chemical reaction for the oxidation of quinoline is shown in Figure 3.

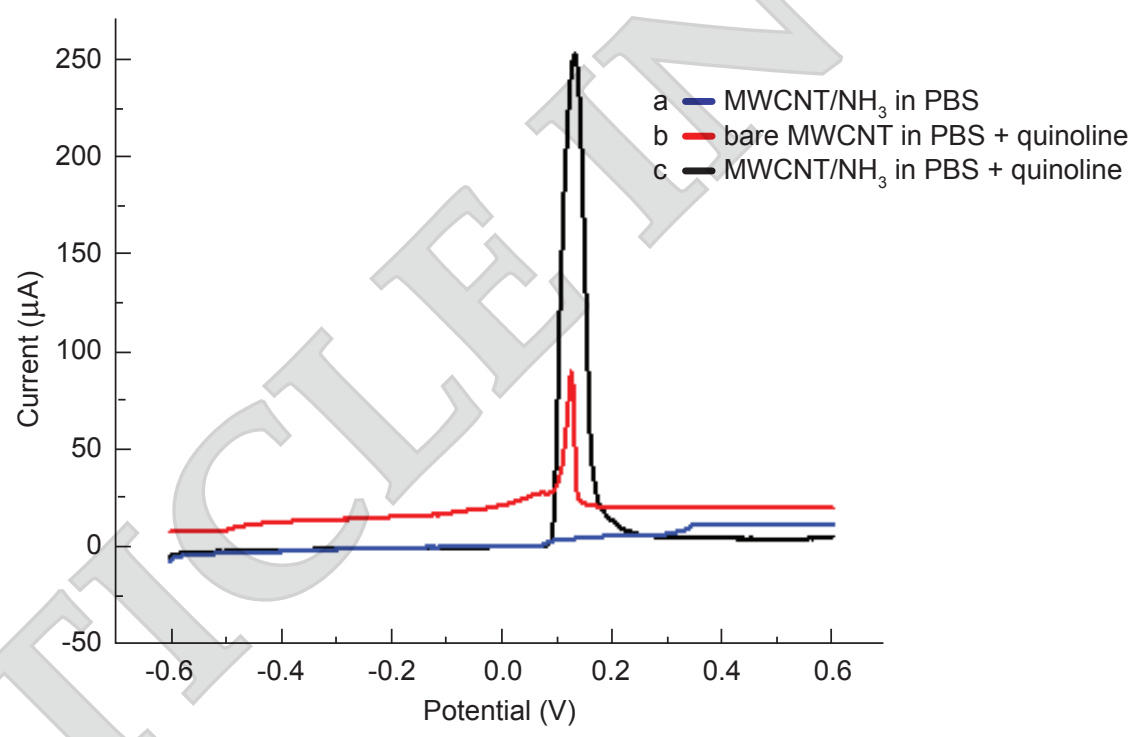

Figure 2. Linear sweep anodic stripping voltammograms (LSASV) curves of (a) ammonia/multi-walled carbon nanotubes ( $\mathrm{NH}_{3} / \mathrm{MWCNT}$ ) electrode in $0.1 \mathrm{M}$ phosphate buffer saline (PBS) solution ( $\mathrm{pH}$ 7.0), (b) bare MWCNT electrode in $0.1 \mathrm{M}$ PBS solution ( $\mathrm{pH}$ 7.0) after addition of $20 \mu \mathrm{M}$ quinoline, (c) $\mathrm{NH}_{3} /$ MWCNT electrode in $0.1 \mathrm{M}$ PBS solution ( $p H$ 7.0) after addition of $20 \mu \mathrm{M}$ quinoline (accumulation potential of $-0.6 \mathrm{~V}$ for $50 \mathrm{~s}$ ).<smiles>c1ccc2ncccc2c1</smiles><smiles>C[13CH]</smiles>

Quinoline<smiles>C1=Cc2ncccc2CC1</smiles><smiles>[Y20][OH+]</smiles>

Quinoline ion<smiles>Oc1cccc2ncccc12</smiles>

8-Hydroxyquinoline

Figure 3. Chemical reaction for the oxidation of quinoline. 
Optimisation of the Working Conditions for Modified Electrode in Quinoline

Various working conditions such as influence of $\mathrm{pH}$ on the current response, effect of accumulation potential and time, effect of varying scan rates and quinoline concentration for the detection of quinoline has been optimised in this work.

\section{Influence of $\mathrm{pH}$ on the Current Response}

In order to investigate the effect of $\mathrm{pH}$ on oxidation response of quinoline, different $\mathrm{pH}$ values of PBS solution were used. Figure 4 shows the relationship between $\mathrm{pH}$ values with the oxidation peak currents of quinoline. When the $\mathrm{pH}$ values were increased from 4.0 to 7.0 , the oxidation signal of quinoline increased gradually with maximum peak current at $\mathrm{pH}$ 7.0. When the $\mathrm{pH}$ was increased further, the oxidation peaks decreased drastically from $\mathrm{pH} 8.0$ to 12.0 .

At different $\mathrm{pH}$ values, the dissociation constant of quinoline also varies. At neutral or alkaline medium, quinoline mainly appears in solution as ion, but at acidic medium, quinoline exists in the form of molecule. The electrophilic reaction occurs more easily for ionic substance than for molecular substance (Wang et al., 2015). Therefore, $\mathrm{pH} 7.0$ of 0.1 M PBS solution was selected to be used for detection of quinoline to achieve high sensitivity.

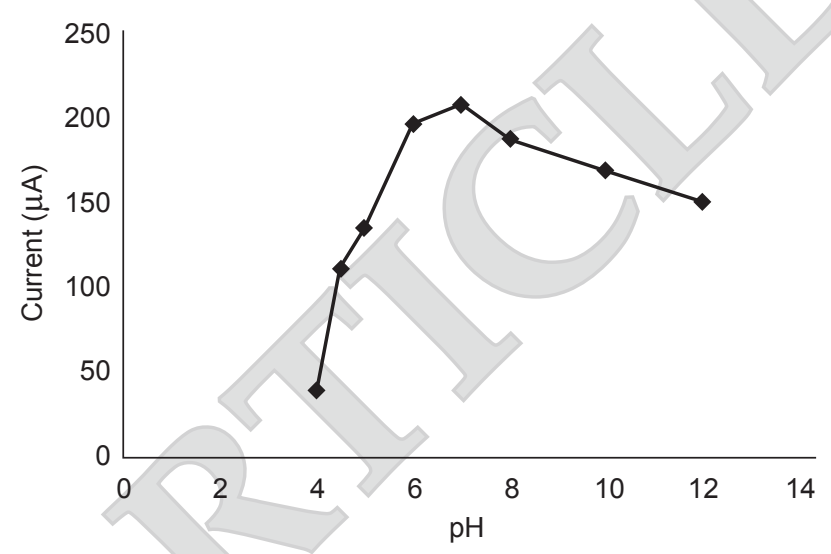

Figure 4. Graph of peak current of $20 \mu \mathrm{M}$ quinoline in different $p H$ of $0.1 \mathrm{M}$ phosphate buffer solution (PBS) solution on ammonia/multiwalled carbon nanotubes $\left(\mathrm{NH}_{3} / \mathrm{MWCNT}\right.$ ) electrode (accumulation potential of $-0.6 \mathrm{~V}$ for $50 \mathrm{~s})$.

\section{Influence of Potential and Accumulation Time}

Different potentials were measured individually to study the influence of accumulation potential towards the oxidation peak current of quinoline. As shown in Figure 5a, the oxidation peak current increased gradually with increasing accumulation potential from -1.0 to $-0.6 \mathrm{~V}$ and then remained constant in range of -0.6 to $0.6 \mathrm{~V}$. Therefore, the accumulation potential of $-0.6 \mathrm{~V}$ was used in further measurements.

Another important aspect in stripping technique is the accumulation time. Anodic stripping voltammetry involves the pre-concentration of analytes on the surface of the working electrode. Thus, adequate period is required for analytes to be deposited on the electrode. In the period of preconcentration step, the working solution is stirred constantly to permit escalation in mass transfer which allows more accumulation of the analyte on the surface of electrode.

Figure $5 b$ represents the effect of accumulation time on the oxidation peak current of $20 \mu \mathrm{M}$ quinoline. Extending the accumulation time from $30-50 \mathrm{~s}$, the oxidation peak current of quinoline was at the highest amplitude at $50 \mathrm{~s}$. It indicated that the longer accumulation period obviously improved the detection sensitivity. Further increase of the duration time up to $120 \mathrm{~s}$, the oxidation peak current of quinoline remained constant, suggesting that the amount of quinoline saturation occurred at the surface of working electrode. Therefore, $50 \mathrm{~s}$ was chosen as the optimum accumulation time for the detection study.

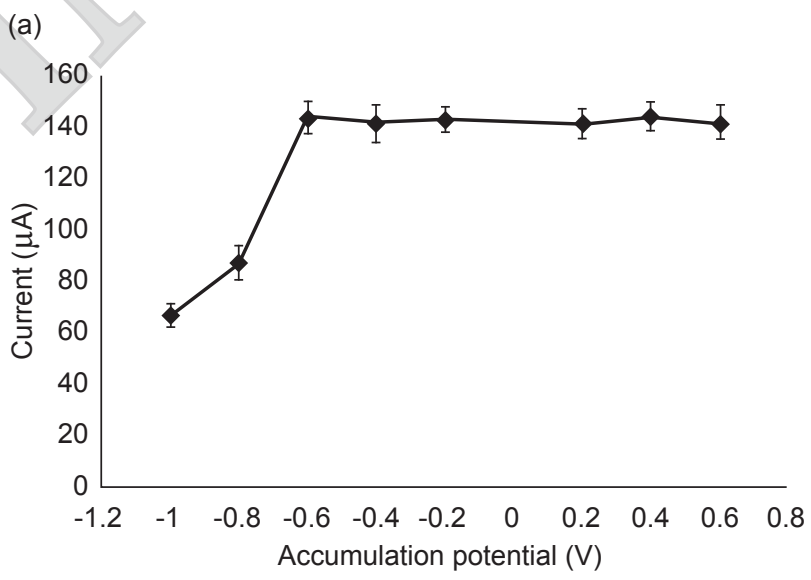

(b)

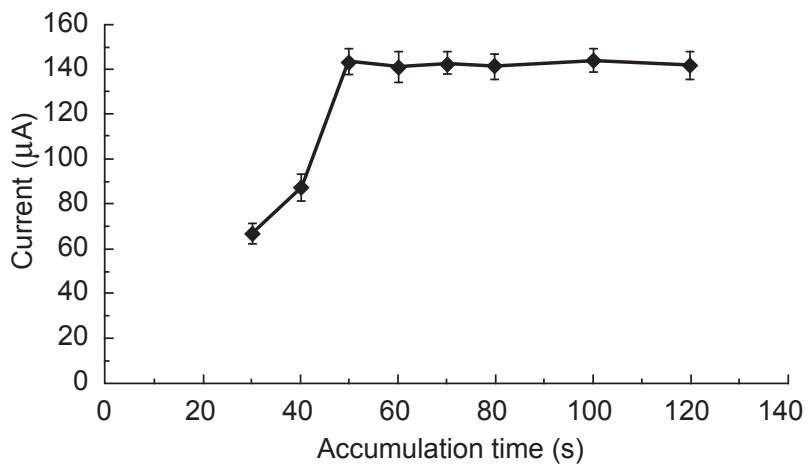

Figure 5. (a) Accumulation potential (V) and (b) accumulation time of the oxidation peak current of $20 \mu \mathrm{M}$ quinoline in $0.1 \mathrm{M}$ phosphate buffer saline (PBS) solution ( $p H$ 7.0). 


\section{Effect of Varying on Scan Rates}

The oxidation responses of quinoline at different scan rates were determined as illustrated in Figure $6 a$. It was found that the oxidation peak current of quinoline at modified $\mathrm{NH}_{3} /$ MWCNT electrode increased linearly with the scan rate $(\mathrm{r})$ in the series from 10 to $100 \mathrm{mV} \mathrm{s}^{-1}$. The responded peak currents (ip) against square root of scan rates $\left(\mathrm{v}^{1 / 2}\right)$ is illustrated in Figure $6 b$. The plot shows linear relationship of ip towards $\mathrm{mVs}^{1 / 2}$ in the range of 10 to $100 \mathrm{mV} \mathrm{s}^{-1}$ with correlation coefficient $\left(\mathrm{R}^{2}\right)$ of 0.9875 suggesting a diffusion controlled process of reactants on the electrode surface.

\section{Effect of Varying Quinoline Concentration and Limit of Detection}

The $\mathrm{NH}_{3} / \mathrm{MWCNT}$ electrode was used to determine different concentrations of quinoline in the range of 2 - $25 \mu \mathrm{mol}$ litre $^{-1}$ using LSASV under the optimised conditions. Figure $7 a$ shows the oxidation peak current of different concentrations of quinoline. It can be observed that a slight shift in the peak potentials of the quinoline with increasing concentration towards positive potential. The calibration graph (Figure $7 b$ ) was linear over the range of 2.0-2.5 $\mu \mathrm{M}$ quinoline with a detection limit of $0.164 \mu \mathrm{M}$. The limit of detection (LOD) was calculated using the $3 \sigma$ method where the $3 \sigma$ LOD was derived from 3SD/S (SD - standard deviation, $S$ - the slope of the calibration graph). The linear regression equation was $\operatorname{Ip}(\mathrm{A})=9.7669 \mathrm{C}(\mu \mathrm{M})$

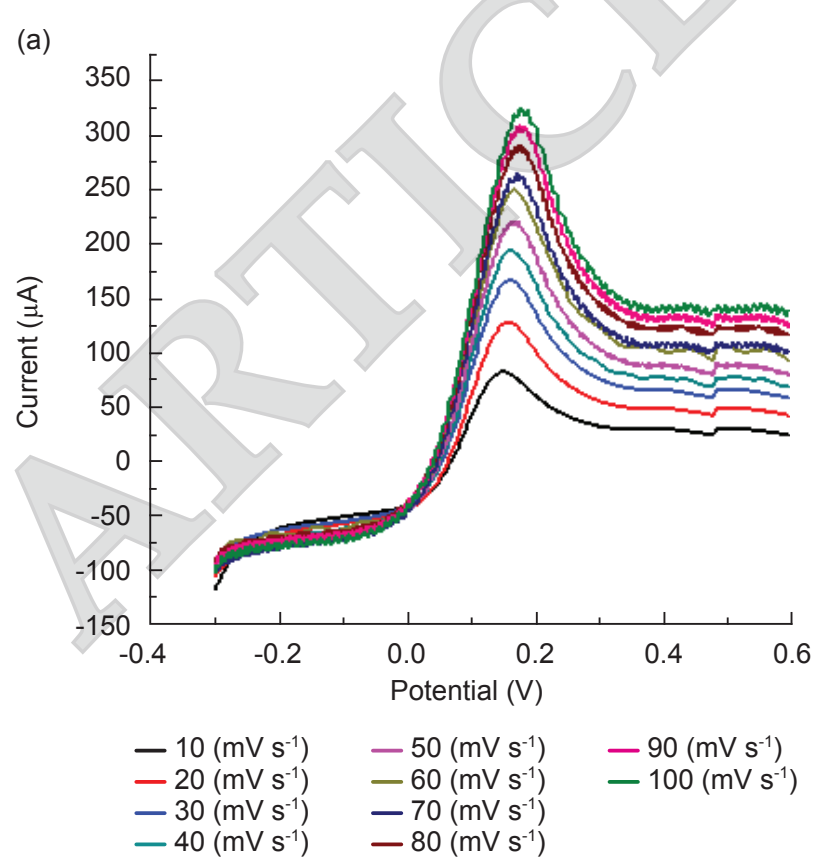

32.866, and the correlation coefficient $(R)$ was 0.9958 , revealing excellent linearity.

As shown in Table 1, the LOD of the modified electrode was compared with other reported previously (Cinti et al., 2014; Hosu et al., 2016; Piovesan and Spinelli, 2014; Rouhani and HajiGhasemi, 2009; Stevic et al., 2012). It can be suggested that the modified electrode in this work has better sensitivity.

\section{Electrochemical Characterisation of Developed Electrode for Quinoline Detection}

The reproducibility study was conducted to determine the precision of the electrodes. Reproducibility result was attained with six similar fabricated $\mathrm{NH}_{3} / \mathrm{MWCNT}$ electrodes in $20 \mu \mathrm{mol}$ litre $^{-1}$ quinoline solution and 0.1 M PBS solution ( $\mathrm{pH}$ 7.0). An excellent RSD value of $2.2 \%$ with average current at $201.83 \mathrm{~mA}$ and SD at 4.28 was obtained.

Stability study for $\mathrm{NH}_{3} /$ MWCNT electrode was investigated using single electrode for 12 weeks. Figure 8 shows that the peak current began to decline from the second week up to week 12 . The current response began to decline due to the etching of carbon nanotubes (CNT) lattice on the working electrode. It was observed that the colour of the reference site was degraded when it was placed in open site for more than 10 weeks. The percentage of stability of $\mathrm{NH}_{3} / \mathrm{MWCNT}$ electrode was reduced about $50 \%$ after 10 weeks and almost $90 \%$ in 12 weeks time. This shows that the electrode has quite a high stability.

(b)

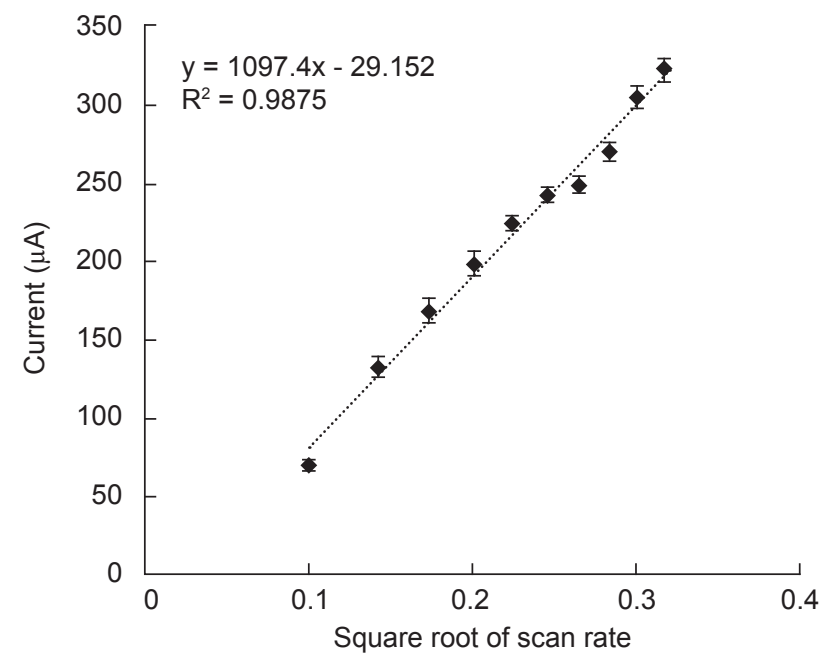

Figure 6. (a) Linear sweeps anodic stripping voltammograms (LSASV) curves of different scan rates of $20 \mu M$ quinoline, (b) oxidation peak current versus square root of scan rate of $20 \mu \mathrm{M}$ quinoline in $0.1 \mathrm{M}$ phosphate buffer saline (PBS) ( $p H$ 7.0) on ammonia/multi-walled carbon nanotubes (NH $/$ MWCNT) electrode (accumulation potential of -0.6 $\mathrm{V}$ for $50 \mathrm{~s}$ ). 
(a)

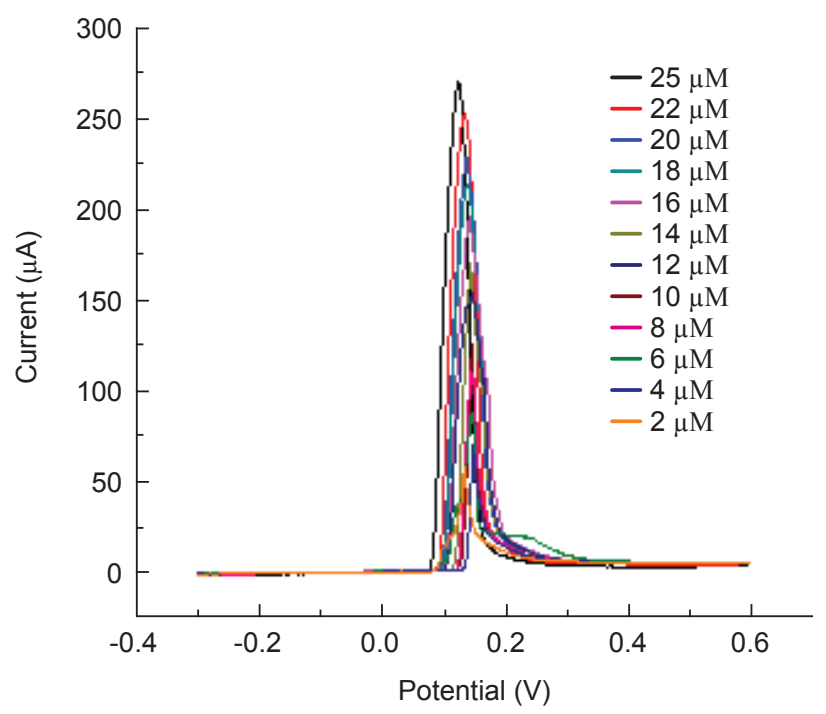

(b)

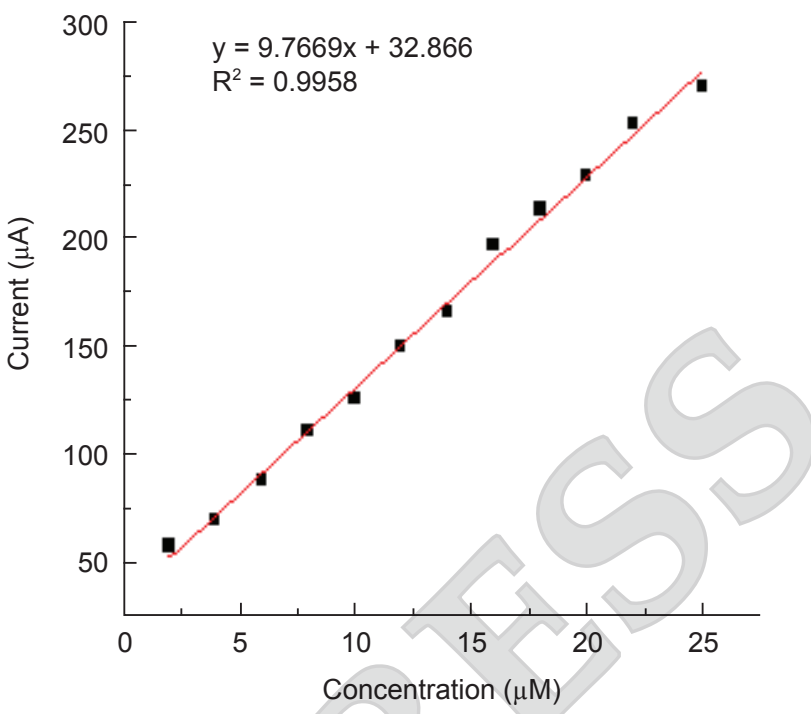

Figure 7. (a) Linear sweeps anodic stripping voltammograms (LSASV) of ammonia/multi-walled carbon nanotubes $\left(\mathrm{NH}_{3} / \mathrm{MWCNT}\right.$ ) electrode in 0.1 $M$ phosphate buffer saline (PBS) solution ( $p H$ 7.0) with different concentrations of quinoline, (b) current intensity versus concentration of quinoline in 0.1 M PBS solution ( $p H$ 7.0) (accumulation potential of $-0.6 \mathrm{~V}$ for $50 \mathrm{~s}$ ).

TABLE 1. ELECTROANALYTICAL APPROACHES USED TO DETECT METABOLITES WITH THE ELECTRODE MATERIALS, SENSITIVITY AND LIMIT OF DETECTION (LOD) OF THE METHOD USED

\begin{tabular}{|c|c|c|c|c|c|}
\hline No. & Metabolite & Electroanalytical technique & $\begin{array}{l}\text { Sensitivity / } \\
\text { inear range }\end{array}$ & LOD $(\mu \mathrm{M})$ & References \\
\hline 1. & 6-Aminoquinoline & Cyclic voltammetry & & 0.43 & Stevic et al. (2012) \\
\hline 2. & Quinoline yellow & Potentiometry & $50-100000$ & 40 & $\begin{array}{l}\text { Rouhani and Haji-Ghasemi } \\
\text { (2009) }\end{array}$ \\
\hline 3. & Quercetin & Cyclic and square-wave voltammetries & $0.5-5.5$ & 0.17 & Piovesan and Spinelli (2014) \\
\hline 4. & Peroxynitrite & Cyclic voltammetry & $2-300$ & 0.2 & Hosu et al. (2016) \\
\hline 5. & Hydrogen peroxide & Cyclic voltammetry & $0-4.5$ & 0.2 & Cinti et al. (2014) \\
\hline
\end{tabular}

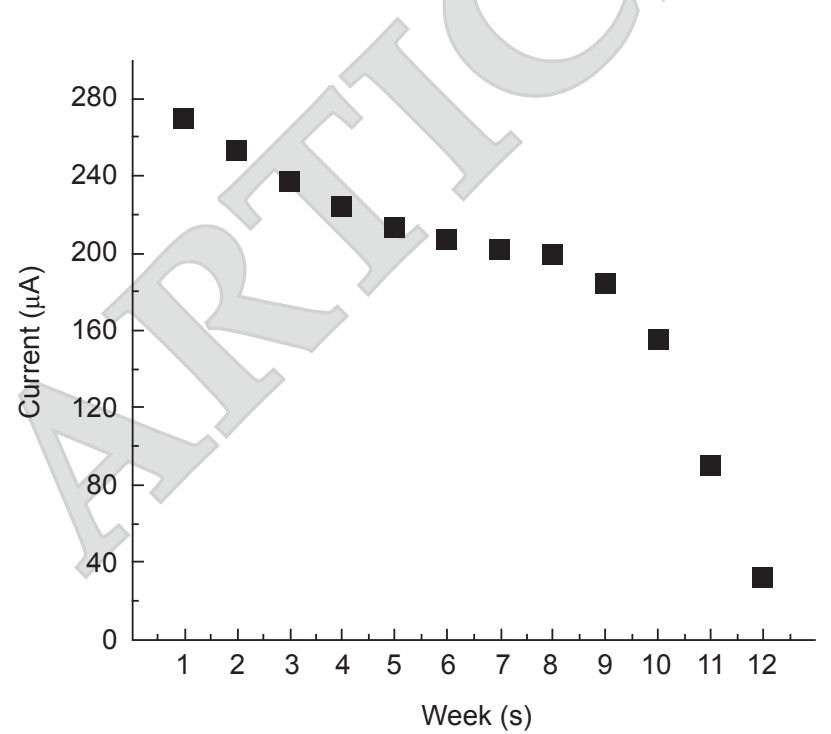

Figure 8. Stability study for $25 \mu M$ quinoline in $0.1 \mathrm{M}$ phosphate buffer saline (PBS) solution ( $\mathrm{pH}$ 7.0) on ammonia/multi-walled carbon nanotubes $\left(\mathrm{NH}_{3} / \mathrm{MWCNT}\right.$ ) electrode (accumulation potential of $-0.6 \mathrm{~V}$ for $50 \mathrm{~s})$.

\section{Application of Modified Electrode to Real Samples}

To validate the methodology, the proposed $\mathrm{NH}_{3} / \mathrm{MWCNT}$ electrode was applied using real samples sourced from both healthy and Ganoderma boninense infected oil palm roots crude extract solutions.

Healthy and Ganoderma boninense infected oil palm roots crude extracts were analysed using LSASV. Figure 9 shows the comparison of LSASV analysis of $\mathrm{NH}_{3} / \mathrm{MWCNT}$ electrode in blank methanol, oil palm roots crude extracts solutions (healthy and Ganoderma boninense infected) at concentration of $100 \mathrm{mg}$ litre $^{-1}$ in methanol and $0.1 \mathrm{M}$ PBS solution ( $\mathrm{pH}$ 7.0). No current peak was observed after running the LSASV analysis of modified electrode with blank methanol solution. Methanol was used as an extraction solvent in the preparation of roots crude extracts. Therefore, methanol was added into the supporting electrolyte of $0.1 \mathrm{M}$ PBS solution ( $\mathrm{pH} 7.0$ ). 
The voltammograms clearly showed that the intensity of Ganoderma boninense infected oil palm roots crude extracts was higher compared to the healthy oil palm roots crude extracts. This is due to the role of secondary metabolite such as quinoline as defence mechanism of plants towards any attack by pathogen. The nature of metabolite exhibits anti-microbial properties that help in the early detection of disease in plants (Meyer et al., 2016).

A study on different concentrations of Ganoderma boninense infected oil palm roots crude extracts was also carried out. Figure 10 shows the (a) voltammograms and (b) linear plot of Ganoderma boninense infected oil palm roots crude extracts ranging from $100 \mathrm{mg}$ litre $^{-1}$ down to $10 \mathrm{mg}$ litre $^{-1}$ concentrations. It can be observed that as the concentration reduced, the peak current showed lower readings. The linear plot gave a linear equation of $y=0.4753 x-2.2894$ with correlation coefficient $\left(R^{2}\right)=0.9879$.

Reproducibility result was attained with six similar fabricated $\mathrm{NH}_{3} /$ MWCNT electrodes in 100 $\mathrm{mg}$ litre $^{-1}$ Ganoderma boninense infected oil palm roots crude extracts solution and 0.1 M PBS solution ( $\mathrm{pH}$ 7.0). An excellent RSD value of $3.11 \%$, SD at 4.28 with average current $46.87 \mu \mathrm{A}$ was obtained in this study.
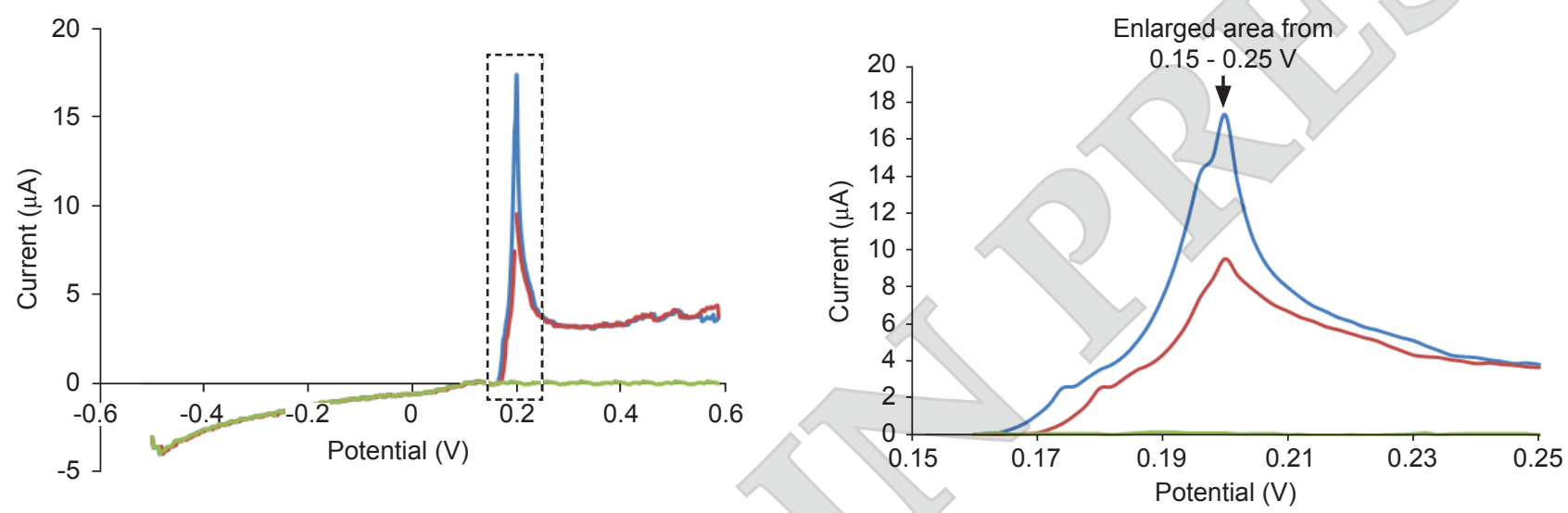

\footnotetext{
- Infected roots crude extracts solution - Healthy roots crude extracts solution - Blank methanol
}

Figure 9. Voltammograms of blank methanol, oil palm roots crude extracts solutions (healthy and Ganoderma boninense infected) at concentration of $100 \mathrm{mg} \mathrm{litre-1}$ in methanol and $0.1 \mathrm{M}$ phosphate buffer saline (PBS) solution ( $\mathrm{pH}$ 7.0). (a)Potential (V) scale from -0.6 to $0.6 \mathrm{~V}$ and (b) enlargement of potential $(\mathrm{V})$ scale from 0.15 to $0.25 \mathrm{~V}$.

(a)

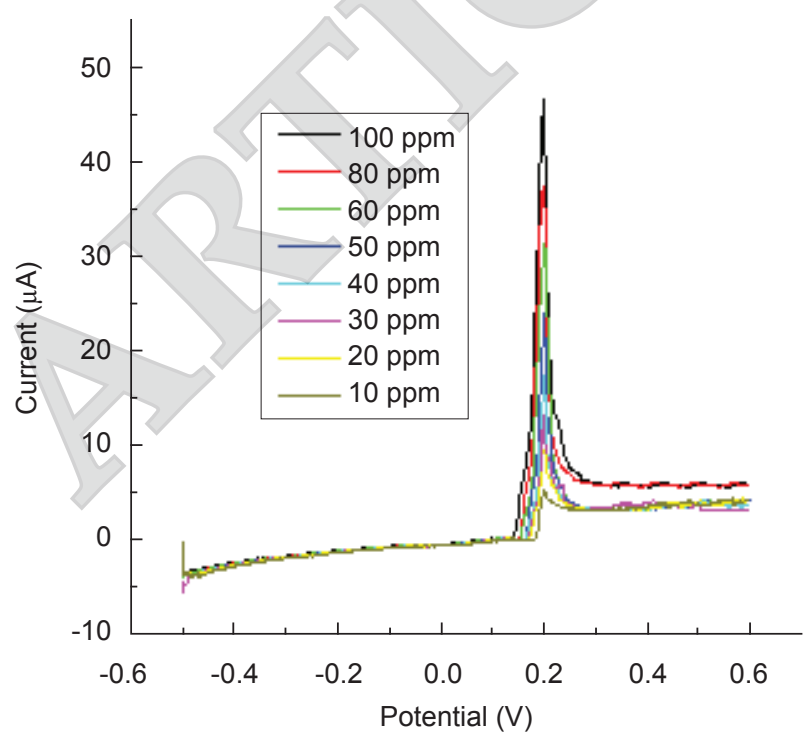

(b)

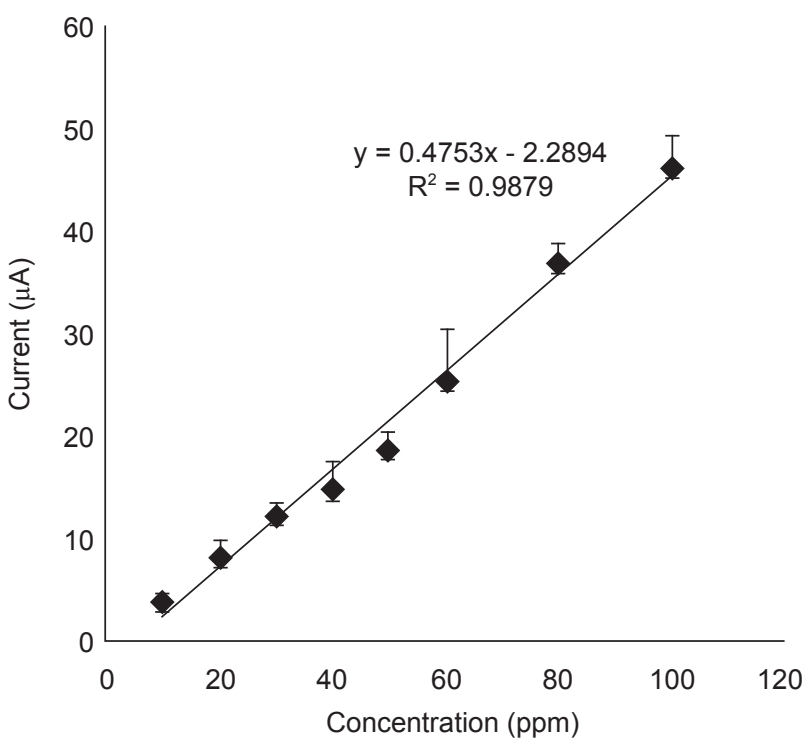

Figure 10. (a) Voltammograms and (b) linear plot of the Ganoderma boninense infected oil palm roots crude extract solutions at different concentrations (100 $\mathrm{mg} \mathrm{litre}^{-1}$ down to $10 \mathrm{mg} \mathrm{litre}^{-1}$ ) (accumulation potential - $0.6 \mathrm{~V}$ for $50 \mathrm{~s}$ ). 


\section{CONCLUSION}

A new fabricated $\mathrm{NH}_{3}$ /MWCNT electrode-based electrochemical sensor through photolithography process was successfully developed for the detection of quinoline. The linear range for quinoline detection was 2.0-2.5 $\mu \mathrm{M}$ under the optimised experimental condition which was applicable for real samples determination, i.e. healthy and Ganoderma boninense infected oil palm roots. The electrode also demonstrated good accuracy, stability and reproducibility, which might be due to contributive unique characteristics of $\mathrm{NH}_{3}$-treated MWCNT interaction between them.

\section{ACKNOWLEDGEMENT}

This work was supported by the Ministry of Higher Education Malaysia, Long-Term Research Grant Schemes (LRGS)-Nanomite and Universiti Putra Malaysia under Grant [5526301; 5526304; 9443101; 9443104].

\section{REFERENCES}

Abdul-Rahim, Z; Yusof, N A; Mohammad-Haniff, M A S; Mohammad, F; Syono, M I and Daud, N (2018). Electrochemical measurements of multiwalled carbon nanotubes under different plasma treatments. Materials, 11: 1902.

Akanbi, F S; Yusof, N A; Abdullah, J; Sulaiman, Y and Hushiarian, R (2017). Detection of quinoline in G. boninense-infected plants using functionalized multi-walled carbon nanotubes: A field study. Sensors, 17(1538): 14.

Azahar, T M; Idris, A S; Abu Hassan, D and Norazlin (2014). Assessment of basal stem rot disease distribution in palm oil plantation using geographical information system. J. Sci. Technol., 6: 81-92.

Bennett, R N and Wallsgrove, R M (1994). Secondary metabolites in plant defense mechanisms. New Phytology, 127: 617-633.

Choon, R L T (2011). Fungal Metabolites for Assessment of Ganoderma boninense Pat. Infection in Oil Palm. Master thesis. Universiti Putra Malaysia, Selangor, Malaysia. 94 pp.

Cinti, S; Arduini, F; Moscone, D; Palleschi, G and Killard, A J (2014). Development of a hydrogen peroxide sensor based on screen-printed electrodes modified with inkjet-printed prussian blue nanoparticles. Sensors, 14: 14222-14234.
Dutse, S W; Yusof, N A; Ahmad, H; Hussein, M Z and Zainal, Z (2012). An electrochemical DNA biosensor for Ganoderma boninense pathogen of the oil palm utilizing a new ruthenium complex, [Ru (dppz) 2 (qtpy)] $\mathrm{Cl}_{2}$. Int. J. Electrochem. Sci., 7: 8105-8115.

Fang, Y and Ramasamy R P (2015). Current and prospective methods for plant disease detection. Biosensors, 4: 537-561.

$\mathrm{Fu}, \mathrm{L}$ and $\mathrm{Yu}, \mathrm{A} \mathrm{M}$ (2014). Carbon nanotubes based thin films: Fabrication, characterization and applications. International J. Electrochemical Science, 36: 40-61.

Hosu, I S; Constantinescu-Aruxandei, D; Jecu, M -L; Oancea, F and Doni, M B (2016). Peroxynitrite sensor based on a screen printed carbon electrode modified with a poly(2,6-dihydroxynaphthalene) film. Sensors, 16: 1975.

Hushiarian, R; Yusof, N A and Dutse, S W (2013). Detection and control of Ganoderma boninense: Strategies and perspectives. Springerpluss, 2: 555.

Ho, Y W and Nawawi, A (1985). Ganoderma boninense Pat. from basal stem rot of oil palm (Elaeis guineensis) in Peninsular Malaysia. Pertanika, 8(3): 425-428.

Idris, AS and Rafidah, AR (2008). Polyclonal antibody for detection of Ganoderma. MPOB Information Series No. 405: 2 pp.

Idris, A S; Kushairi A; Ariffin D and Basri, M W (2006). Technique for inoculation of oil palm geminated seeds with Ganoderma. MPOB Information Series No. 314: 4 pp.

Idris, A S; Rajinder, A; Madihah and Wahid, M B (2006). Multiplex PCR-DNA kit for early detection and identification of Ganoderma species in oil palm. MPOB Information Series No. 73: 2 pp.

Khairuddin, H (1990). Basal Stem Rot of Oil Palm: Incidence, Etiology and Control. Master of Agriculture Science thesis. Universiti Pertanian Malaysia, Selangor, Malaysia. $151 \mathrm{pp}$.

Lisnawati; Hanum, H and Tantawi, AR (2016). Survey of basal stem rot disease on oil palms (Elaeis guineensis Jacq.) in Kebun Bukit Kijang, North Sumatera, Indonesia. IOP Conf. Ser. Earth Environ. Sci., 41: 012007.

Madihah, A Z; Idris, A S and Rafidah, A R (2014). Polyclonal antibodies of Ganoderma boninese isolated from Malaysian oil palm for detection of oil palm basal stem rot disease. African J. Biotechnol., 13(34): 3463. 
Meyer, J; Murray, S L and Berger, D K (2016). Physiological and molecular plant pathology signals that stop the rot: Regulation of secondary metabolite defences in cereals. Physiol. Mol. Plant Pathol., 94: 156166.

Mohd Su'ud, M; Loonis, P and Idris, A S (2007). Towards automatic recognition and grading of Ganoderma infection pattern using fuzzy systems. Int. J. Medical, Heal. Biomed. Bioeng. Pharm. Eng., 1(1): 1-6.

Nurnadiah, E; Aimrun, W; Amin, M S M and Idris, A S (2014). Preliminary study on detection of basal stem rot (BSR) disease at oil palm tree using electrical resistance. Agric. Sci. Procedia, 2: 90-94.

Nusaibah, S A; Siti Nor Akmar, A; Idris, A S; Sariah, M and Mohamad Pauzi, Z (2016). Involvement of metabolites in early defense mechanism of oil palm (Elaeis guineensis Jacq.) against Ganoderma disease. Plant Physiol. Bioch., 109: 156-165.

Piovesan, J V and Spinelli, A (2014). Determination of Quercetin in a pharmaceutical sample by squarewave voltammetry using a poly(vinylpyrrolidone)modified carbon-paste electrode. J. Braz. Chem. Soc., 25(3): 517-525.
Rouhani, S and Haji-Ghasemi, T (2009). Novel PVC-based coated graphite electrode for selective determination of quinoline yellow. J. Iran. Chem. Soc., 6(4): 679-685.

Stević, M C; Ćirić-Marjanović, G; Marjanović, B; Ignjatović, L M and Manojlović, D (2012). The electrochemical oxidation of 6-aminoquinoline: Computational and voltammetric study. J. Electrochem. Soc., 159(11): G151-G159.

Taurino, I; Carrara, S; Giorcelli, M; Tagliaferro, A and De Micheli, G (2012). Comparison of two different carbon nanotube-based surfaces with respect to potassium ferricyanide electrochemistry. Surf. Sci., 606: 156-160.

Wang, C R; Wang, J; Ma, X G; Li, H and Zhang, $S$ Z (2015). Mineralization of quinoline by BDD anodes: Variable effects and its effluent characteristics. J. Chem., 2015(4): 1-8. DOI: 10.1155 / $2015 / 617850$

Wong, L-C; Bong, C F J and Idris, A S (2012). Ganoderma species associated with basal stem rot disease of oil palm. Am. J. Appl. Sci., 9(6): 879-885. 